\title{
Escherichia blattae
}

National Cancer Institute

\section{Source}

National Cancer Institute. Escherichia blattae. NCI Thesaurus. Code C86379.

A species of facultatively anaerobic, Gram-negative rod shaped bacteria assigned to the phylum Proteobacteria. This species is motile, non-spore forming, catalase positive, indole, citrate, and urease negative, does not produce hydrogen sulfide, and ferments xylose, but not mannitol. E. blattae was isolated from the hind-gut of cockroaches and is nonpathogenic to humans. 